\title{
Research on User Loyalty of Instant Messaging Tools
}

\author{
Wang Chun-zhi ${ }^{1}$ Wang Kai $^{2}$ \\ ${ }^{1}$ College of Economics and Management, Dalian Nationalities University, Dalian, China \\ ${ }^{2}$ School of Management, Zhejiang University, Hangzhou, China
}

\begin{abstract}
User loyalty is crucial to the survival of instant message tool's provider. In order to recognize the influence factors of user loyalty and the influence mechanism, an empirical investigation of 379 subjects is conducted. Based on the structural equation model analysis, service quality and satisfaction are confirmed to have positive influence on loyalty. Service quality is the most important factor, because its direct influence on loyalty and indirect influence with satisfaction as mediator. Besides this, perceived value is positively influenced by service quality, and has positive influence on satisfaction. Based on these conclusions, the study suggests IM providers improve user loyalty by advancing service quality first, with making users more aware of the providers' empathy as the key measure.
\end{abstract}

Keywords: instant message industry; service quality; satisfaction; perceived value; loyalty

\section{Introduction}

Instant Message (IM) is a kind of software that enables users to identify and

this paper is sponsored by Jilin Social Sciences Planning Program (2008Bglx22), and sponsored by Scientific Research Launching Fund of Dalian Nationalities University (20086207). communicate with his friends, such as MSN and QQ. IM provider's profit mainly derives from advertisements and affiliated businesses, such as QQ games and QQ integral cards. However, abundance of users is the most important source of advertisements and other affiliated businesses profits. Therefore, owning a huge group of loyal users is crucial to IM providers. Since the cost to develop a new user is 4 times as much as it to maintain an old user, identifying what factors influence and how these factors influence users' loyalty is the guarantee to IM providers' survival.

Literature on users' loyalty's influencing factors and influencing mechanism is concluded employing general service industries as context, such as hotel, bank, and airlines. The significant difference between IM and those service industries is that, IM is open to users with no charge. So, as far as IM industry is concerned, the existing conclusions generated from other service industries can not be taken as granted. Based on this view, the present research employs related theories to modeling the relationships between IM's service quality, satisfaction, perceived value and loyalty. By doing this, the influencing factors on IM users' loyalty and influencing mechanism are specified, and this can be taken as foundation for both future research and IM provider's business administration.

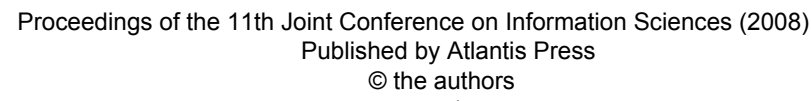




\section{Theory Background and Hypotheses}

\subsection{Service Quality, User Satisfaction and Loyalty}

Service quality, as perceived by consumers, stems from a comparison of what the feel service firms should offer (expectations) with their perceptions of the performance of firms providing the services. IM's service quality in this paper is users' comparison results of what the IM provider should offer with the actual performance by that IM provider.

The expectation-performance effect not only generates service quality, but also consumer satisfaction. Here, satisfaction is a psychological judgment and can creates emotion. As the gap between expectation and performance, if the performance is higher than expectation, satisfaction is generated; if not, dissatisfaction.

Being also a cognitive concept as service quality and satisfaction, loyalty is a long time-course result. Loyalty can be defined as a deeply held commitment to re-buy or re-patronize a preferred product/service consistently in the future. So, user loyalty in this paper can be taken as users' commitment and willingness to use a certain IM consistently.

The relationships between service quality, satisfaction and loyalty have been studied in a large body of literature. Agreements have achieved that, service quality positively influences satisfaction, and satisfaction positively determines loyalty. When comes to service quality and loyalty, some studies argue that service quality determines loyalty directly, while others argue that the determination is indirectly. So, in IM context, the paper puts forward the following hypotheses.

H1: IM's service quality positively influences user satisfaction

H2: IM's service quality positively influences user loyalty
H3: user satisfaction positively influences user loyalty

\subsection{Service Quality VS Perceived Value}

Zeithaml (1988) defines perceived value as "it is the consumer's overall assessment of the utility of a product based on perceptions of what is received and what is given." That is perceived value is the remaining of what a consumer obtains subtracted by what he pay for it. When a consumer pays for a certain service, he will expect some kind of return, such expectation and paying out is both contained in the conception of service quality and perceived value. Another sense is that, on the time course of cognition, service quality is prior to perceived value. Only after recognizing the service quality should a consumer make judgment on whether he gets the ideal return against his paying out.

Taking short message service as context, Tung Lai Lai (2004) confirms that service quality has positive influence on perceived value. When a user uses a certain IM, he pays cost in various forms, such as time cost, learning cost, internet fees. With such cost, service quality is the intuitionistic result, and it will determine the user's judgment about whether the service is valuable to his corresponding paying out. Therefore, IM's service quality may have positive influence on perceived value.

H4: IM's service quality positively influences user's perceived value

\subsection{Perceived Value VS Satisfaction}

There are some disputes on the relationship between perceived value and satisfaction. Fornell (1996) demonstrates that "customer satisfaction is more quality-driven than value- or pricedriven"; nevertheless, perceived value also affects customer satisfaction. Later, Cronin (2000) reinforced this by showing

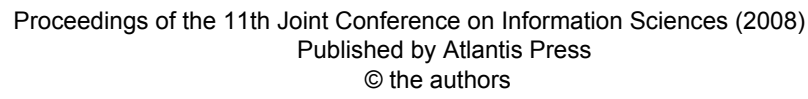


that perceived value is a "significant predictor of satisfaction".

In this paper's context, user's perceived value can makes him a sense whether his using of this IM is valuable and advisable. This sense can lead to his satisfaction or dissatisfaction. According to this thought, the relationship between the users' perceived value of IM and his satisfaction is hypothesized as following.

H5: user's perceived value positively influences his satisfaction

\subsection{Perceived Value VS Loyalty}

Perceived value is "the fundamental basis for all marketing activity" (Holbrook, 1994). And high value is one primary motivation for customer patronage. In this regard, Sirdeshmukh, Singh, and Sabol (2002) argue that perceived value is a superordinate goal and loyalty is a subordinate goal, as it is a behavioral intention. According to goal and action identity theories, a superordinate goal is likely to regulate subordinate goals. Thus, perceived value regulates "behavioral intentions of loyalty toward the service provider as long as such relational exchanges provide superior value" (Sirdeshmukh, 2002). Prior empirical research has identified perceived value as a major determinant of loyalty in such settings as telephone services, airline travel, and retailing services. In light of the preceding discussion and findings, it is proposed in the IM context that:

H6: user's perceived value positively influences his loyalty

Integrating the 6 hypotheses proposed above, the research model of this paper can be shown as following.

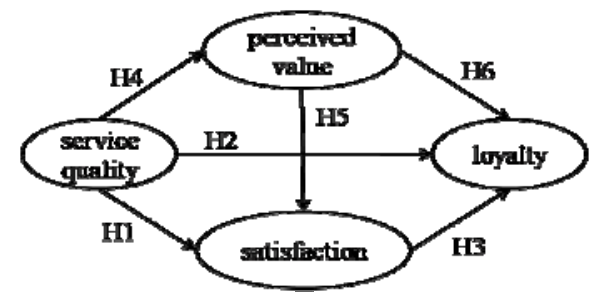

Fig. 1: Research Model

\section{Research Design}

Questionnaire of this study is consisted of service quality scale, user satisfaction scale, user loyalty scale and perceived value scale. The 4 scales are modified taking the studies of Parasuraman, A., Zeithaml,V. A. \& Berry, L.L. (2005), Bhattacherjee (2001), Chen Mingliang (2003), and Sang Hui (2007) as references.

After the questionnaire's forming, an investigation was conducted during the period from December, 2007 to February, 2008. Also, in order to make the investigation situation closer to users' actual application environment, the investigation was done on MSN and QQ.

Finally, 463 questionnaires were sent out, and 379 of them were effective and are used in later data analysis. In the group of subjects, $53.56 \%$ are male with $46.44 \%$ female. $96.59 \%$ of the subjects are from 18 to 30 . Although the age distribution is too centralized, this result is true in real application background. Therefore, the later statistical analysis results based on the sample data can be generalized to the whole instant message industry.

AMOS 4.0 software is employed to complete the structural equation modeling.

\section{Reliability and Validity of Questionnaire}




\subsection{Reliability Analysis}

Reliability means whether the investigation results with the same questionnaire in more than one time are consistent with each other. Usually, Cronbach $\alpha$ is used to represent the reliability of a scale. The Cronbach $\alpha$ efficient of the 4 scales in this study is shown in Table1.

Table 1: Cronbach $\alpha$ coefficients of the scales

\begin{tabular}{|c|c|c|}
\hline Scale & $\begin{array}{c}\text { Number of } \\
\text { Items }\end{array}$ & Cronbach $\boldsymbol{\alpha}$ \\
\hline $\begin{array}{c}\text { Service } \\
\text { Quality }\end{array}$ & 18 & 0.891 \\
\hline $\begin{array}{c}\text { User } \\
\text { Satisfaction }\end{array}$ & 4 & 0.876 \\
\hline User Loyalty & 11 & 0.866 \\
\hline $\begin{array}{c}\text { Perceived } \\
\text { Value }\end{array}$ & 6 & 0.899 \\
\hline
\end{tabular}

Ma Qingguo (2002) suggests that if Cronbach $\alpha$ larger than 0.7, then the scale is reliable. Since the Cronbach $\alpha$ coefficients in this study are all larger than 0.8 , it can be conclude that, the reliability of the 4 scales here all have excellent reliability.

\subsection{Validity Analysis}

Content validity and construct validity are usually used to measure the validity of scale. Since the scales employed by this study are all from existing literature, it can be believed that the 4 scales are good in content validity. As far as structural validity is concerned, factor analysis is conducted, and the results are shown in Table 2, 3, 4 and 5 .

Table 2: Factor Analysis of Service Quality Scale

\begin{tabular}{|c|c|c|c|c|c|}
\hline Dimension & \multicolumn{1}{|c|}{ Item } & Efficiency & Responsiveness & Empathy & Assurance \\
\hline \multirow{7}{*}{ Efficiency } & $\begin{array}{c}\text { The interface of the IM is } \\
\text { friendly }\end{array}$ & 0.765 & 0.060 & 0.248 & -0.012 \\
\cline { 2 - 6 } & $\begin{array}{c}\text { It is easy to acquire the } \\
\text { functions of this IM }\end{array}$ & 0.758 & 0.093 & 0.055 & 0.000 \\
\cline { 2 - 6 } & $\begin{array}{c}\text { It is easy of log in this IM } \\
\text { hardware, software an internet } \\
\text { are easy to reach }\end{array}$ & 0.708 & 0.216 & 0.098 & 0.006 \\
\cline { 2 - 6 } & $\begin{array}{c}\text { It is easy to operate the } \\
\text { denotations of this IM }\end{array}$ & 0.612 & 0.029 & -0.096 & 0.257 \\
\cline { 2 - 6 } & $\begin{array}{c}\text { The layout of this IM is } \\
\text { convenient to use }\end{array}$ & 0.595 & 0.212 & 0.358 & 0.098 \\
\cline { 2 - 6 } & $\begin{array}{c}\text { This IM can satisfy my } \\
\text { demand for instant } \\
\text { communication }\end{array}$ & 0.536 & 0.313 & 0.160 & 0.119 \\
\hline \multirow{7}{*}{ Responsiveness } & $\begin{array}{c}\text { The provider replies to my } \\
\text { questions immediately }\end{array}$ & 0.132 & 0.867 & 0.128 & 0.129 \\
\cline { 2 - 6 } & $\begin{array}{c}\text { The resolution provided by } \\
\text { the provider is clear and } \\
\text { effective }\end{array}$ & 0.096 & 0.836 & 0.170 & 0.134 \\
\cline { 2 - 6 } & $\begin{array}{c}\text { The provider has channels to } \\
\text { collect my questions }\end{array}$ & 0.270 & 0.689 & 0.230 & 0.164 \\
\cline { 2 - 6 } & $\begin{array}{c}\text { The IM reminds me my } \\
\text { unsafe logging in state }\end{array}$ & 0.077 & 0.623 & 0.413 & 0.226 \\
\cline { 2 - 6 } & $\begin{array}{c}\text { The IM provides me pellucid } \\
\text { directions }\end{array}$ & 0.418 & 0.511 & 0.183 & 0.164 \\
\hline \multirow{2}{*}{ Empathy } & $\begin{array}{c}\text { The IM can shield me from } \\
\text { unpleasant information }\end{array}$ & 0.152 & 0.207 & 0.786 & 0.156 \\
$\begin{array}{c}\text { The IM provides me } \\
\text { alternative safe protecting } \\
\text { active X }\end{array}$ & 0.196 & 0.207 & 0.748 & 0.222 \\
\hline
\end{tabular}




\begin{tabular}{|c|c|c|c|c|c|}
\hline & $\begin{array}{c}\text { The service innovation of this } \\
\text { IM fits me well }\end{array}$ & 0.251 & 0.343 & 0.647 & 0.008 \\
\hline \multirow{7}{*}{ Assurance } & $\begin{array}{c}\text { The servicers own } \\
\text { professional knowledge and } \\
\text { ability }\end{array}$ & -0.008 & 0.101 & -0.005 & 0.848 \\
\cline { 2 - 5 } & $\begin{array}{c}\text { Different services are } \\
\text { cooperating to solve my } \\
\text { problems }\end{array}$ & 0.097 & 0.211 & 0.182 & 0.842 \\
\cline { 2 - 6 } & $\begin{array}{c}\text { There is online consulting } \\
\text { service on the IM }\end{array}$ & 0.164 & 0.256 & 0.311 & 0.634 \\
\hline
\end{tabular}

Table 4: Factor Analysis of Perceived Value

Table 3: Factor Analysis of Satisfaction Scale

\begin{tabular}{|c|c|c|c|}
\hline \multirow{2}{*}{ Item } & \multirow{2}{*}{$\begin{array}{c}\text { Factor } \\
\text { Loading }\end{array}$} & Item & $\begin{array}{c}\text { Factor } \\
\text { Loading }\end{array}$ \\
\hline & & & \\
\hline I am satisfied with the functions of the & 0.866 & $\begin{array}{l}\text { is valuable } \\
\end{array}$ & 0.921 \\
\hline $\begin{array}{c}\text { IM } \\
\text { I am satisfied with my choosing this IM }\end{array}$ & 0.855 & $\begin{array}{l}\text { Compared with functions and service, } \\
\text { my paying out is valuable }\end{array}$ & 0.895 \\
\hline $\begin{array}{c}\text { Compared with other IM, I am more } \\
\text { satisfied with the one }\end{array}$ & 0.850 & $\begin{array}{l}\text { Compared with other IM, I am more } \\
\text { satisfied with the one }\end{array}$ & 0.885 \\
\hline $\begin{array}{c}\text { I am satisfied with the affiliated } \\
\text { services and functions }\end{array}$ & 0.845 & $\begin{array}{l}\text { I am satisfied with the affiliated services } \\
\text { and functions }\end{array}$ & 0.846 \\
\hline
\end{tabular}

Table 5: Factor Analysis of Loyalty Scale

\begin{tabular}{|c|c|c|c|c|c|}
\hline Dimension & Item & $\begin{array}{c}\text { Continuance } \\
\text { Use }\end{array}$ & $\begin{array}{l}\text { Recommend } \\
\text { Intention }\end{array}$ & $\begin{array}{l}\text { Intercross } \\
\text { Use }\end{array}$ & $\begin{array}{c}\text { Price } \\
\text { Endurance }\end{array}$ \\
\hline \multirow{3}{*}{$\begin{array}{l}\text { Continuance } \\
\text { Use }\end{array}$} & I have been using this IM ever & 0.867 & 0.177 & 0.005 & 0.027 \\
\hline & $\begin{array}{l}\text { I will continue to use this IM } \\
\text { in future }\end{array}$ & 0.832 & 0.205 & 0.170 & 0.057 \\
\hline & $\begin{array}{l}\text { I consider this IM as my first } \\
\text { online communication tool }\end{array}$ & 0.798 & 0.189 & 0.143 & 0.082 \\
\hline \multirow{3}{*}{$\begin{array}{l}\text { Recommend } \\
\text { Intention }\end{array}$} & $\begin{array}{l}\text { I will introduce the advantages } \\
\text { of this IM to others actively }\end{array}$ & 0.127 & 0.830 & 0.223 & 0.206 \\
\hline & $\begin{array}{c}\text { I will recommend this IM } \\
\text { when someone inquires me for } \\
\text { advice }\end{array}$ & 0.289 & 0.813 & 0.180 & 0.201 \\
\hline & $\begin{array}{c}\text { I will encourage my friends to } \\
\text { use this IM }\end{array}$ & 0.329 & 0.755 & 0.257 & 0.114 \\
\hline \multirow{3}{*}{$\begin{array}{l}\text { Intercross } \\
\text { Use }\end{array}$} & $\begin{array}{l}\text { I will not use the free service, } \\
\text { but also the charged service }\end{array}$ & 0.026 & 0.078 & 0.842 & 0.169 \\
\hline & $\begin{array}{l}\text { I will use the affiliated service } \\
\text { of this IM }\end{array}$ & 0.196 & 0.239 & 0.797 & 0.141 \\
\hline & $\begin{array}{c}\text { I will receive service by } \\
\text { visiting the website of this IM }\end{array}$ & 0.128 & 0.309 & 0.709 & 0.137 \\
\hline \multirow{2}{*}{$\begin{array}{c}\text { Price } \\
\text { Endurance }\end{array}$} & $\begin{array}{l}\text { If it is no more free to use this } \\
\text { IM, I will still use it }\end{array}$ & 0.065 & 0.151 & 0.110 & 0.905 \\
\hline & $\begin{array}{c}\text { If the affiliated service is } \\
\text { charged, I will still use this IM }\end{array}$ & 0.074 & 0.273 & 0.353 & 0.731 \\
\hline
\end{tabular}

\section{Structure Equation Modeling Results}

In order to evaluate the fitness of the research model, AMOS 5.0 is employed to test the structural equation model, and the validation results of the 6 hypotheses 
have been got as shown in Table 6 and Figure 2.

Table 6: Fitness Indexes of The Structrual Equation Model

\begin{tabular}{|c|c|c|c|c|c|c|}
\hline $\begin{array}{c}\chi^{2} / \mathbf{d} \\
\mathbf{f}\end{array}$ & GFI & $\begin{array}{c}\text { AG } \\
\text { FI }\end{array}$ & NFI & TLI & $\begin{array}{c}\text { C } \\
\text { FI }\end{array}$ & $\begin{array}{c}\text { RMS } \\
\text { EA }\end{array}$ \\
\hline $\begin{array}{c}1.97 \\
4\end{array}$ & 0.85 & 0.83 & 0.86 & 0.92 & 0.9 & 0.051 \\
\end{tabular}

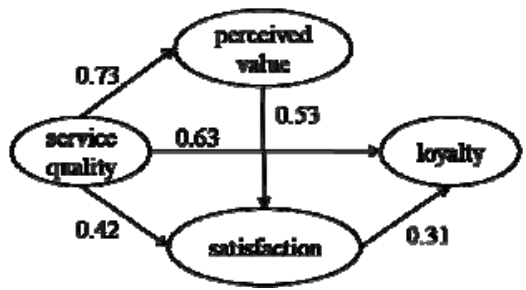

Fig.2: the Empirical Structural Equation Model

According to Table 6, the fitness of the structural equation model is good, because the two key indexes CFI is larger than 0.9, and RMSEA is smaller than 0.06. The good fitness of the structural equation model means the relationships between variables assumed by this study are reasonable.

Whether those 6 hypotheses are validated is shown in Figure 2. Compared with the hypothesized research model in Figure 1, all the 6 hypotheses are confirmed except $\mathrm{H} 6$, which represents the positive influence of perceived value on loyalty.

\section{Discussion}

According to the theoretical background and statistical results, in the context of instant message industry, service quality not only positively determines loyalty directly, but also positively determines loyalty indirectly with satisfaction as mediator. Besides this, perceived value has no significant influence on user loyalty, but has positive influence on satisfaction. The analysis results are discussed in detail as following.

First, despite the positive influence of satisfaction on loyalty, service quality is the original determinant of user loyalty, because service quality positively influences on perceived value and satisfaction, and service quality can positively influence on loyalty together with satisfaction. Therefore, when attempting to improve user loyalty, we should take advancing service quality as the first step. For example, provide 24 hour online consulting services, make users' using more convenient and respond to users' suggestions and complaints immediately, and so on.

Second, the service quality of IM can be divided into 4 dimensions, which are efficiency, responsiveness, empathy, and assurance. Although not shown in Figure 2 , empathy has the largest contribution to service quality with the regression coefficient 0.85 . This indicates that, the user pay more attention to whether the IM's functions and services concern his demand and habits. If the IM is more customized, then the user will be more aware of empathy, so the service quality will be perceived higher. Since service quality can positively determine loyalty directly, if we want to improve service quality, then delivering more empathy to users should be taken as the most prior channel.

Third, perceived value has positive influence on satisfaction, but not on loyalty. According to Oliver (1997), consumer loyalty is a long-time result. So it is hardly to get loyalty from perceived value, because users usually use a certain IM for a long time, and have built up their opinions solidly. In the fact of this, such a utilitarian cognition concept as perceived value merely has power to change a user's loyalty intention and behavior. However, satisfaction can change every time when the user interacts with IM. So, 
as long as the user consider his returning is not equal or higher than his paying out, he will perceived the IM as being low value, and form his dissatisfaction. And if such process repeats several times during the user's using, then his attitude of satisfaction/dissatisfaction can lead to his loyalty/not loyalty.

\section{Summary}

In the light of existing literature about service quality, consumer satisfaction, perceived value, and loyalty, the present study conducts empirical investigation to see what and how influence user loyalty in the context of instant message industry. Recognizing the influencing factors of user loyalty and the influencing mechanism, this study can benefit the IM providers by providing them with the approximate suggestions. In order to achieve high user loyalty, the IM provider should better pay more attention to improve service quality, and also make users being more aware of what they get is more than what they cost. Through this, users will be more satisfied, and high loyalty can be generated.

\section{References}

[1] A. Parasuraman, V. A. Zeithaml, and L.L. Berry. A Multiple-Item Scale for Measuring Consumer Preceptions of Service Quality. Journal of Retailing, vol. 64, 1, pp.12-40, Februray 1988

[2] R.L. Oliver. Whence Consumer Loyalty?. Journal of Marketing, vol.63, 1,pp.33-44, 1999

[3] Cronin, and Taylor. Measuring Service Quality - A Reexamination and Extension. Journal of Marketing, vol.56, 3, pp.55-68, 1992

[4] A. Parasuraman, V. A. Zeithaml, and Malhotra. E-S-QUAL: A MultipleItem Scale for Assessing Electronic Service Quality. Journal of Service Research,vol.7, 3, pp. 213-234, 2005

[5] A. Bhattacherjee. An Empirical Analysis of the Antecedents of Electronic Commerce Service Continuance. Decision Support Systems, vol. 32, 2, pp. 201-214,2001

[6] Chen Mingliang. Empirical Research on Influencing Factors of Consumer Loyalty. Journal of Management Science in China, vol.6, 5, pp.7278,2003

[7] Sanghui. Switching Cost of Consumers Online. Nankai Business Review, vol.10, 6, pp.33-39, 2007 